\title{
Effect of Fungicides on Lesion Expansion of Late Blight of Potato
}

\author{
Saidul Islam ${ }^{1 *}$, Rahamatulla Middya ${ }^{1}$, Bholanath Mondal $^{1}$ and Dinesh Chandra Khatua ${ }^{2}$ \\ ${ }^{1}$ Department of Plant Protection, Palli-Siksha Bhavana (Institute of Agriculture), \\ Visva-Bharati, Sriniketan 731236, India \\ ${ }^{2}$ Department of Plant Pathology, Bidhan Chandra Krishi Viswavidyalaya, \\ Mohanpur, Nadia, India \\ *Corresponding author
}

\begin{tabular}{|c|c|}
\hline \multicolumn{2}{|r|}{ A B S T R A C T } \\
\hline & \multirow{6}{*}{$\begin{array}{l}\text { The experiment was conducted in field condition during } 2015-2016 \text { at Birbhum district, } \\
\text { the Lateritic Red and Undulating Agro-climatic region of West Bengal to find out effect of } \\
\text { fungicides against lesion expansion of late blight of potato (cv. Kufri Jyoti). Typical late } \\
\text { blight lesions on leaves were identified and tagged in the field. Water suspension of } \\
\text { different fungicides ( } 0.1 \% \text { of commercial formulation) was sprayed separately on the } \\
\text { infected leaves with a hand sprayer. Size of the individual spot was measured before and } \\
96 \text { hours after spraying. Suitable control was maintained without spraying of fungicide. } \\
\text { Per cent change of infected area was calculated } 96 \text { hours after spraying. Infected area was } \\
\text { increased after } 96 \text { hours both in control and treatments. Experimental fungicides could not } \\
\text { prevent lesion expansion totally. But four fungicides (Ethaboxam } 40 \% \text { SC, Chlorothalonil } \\
33 \%+\text { Metalaxyl 3.3\% SC, Chlorothalonil } 75 \% \text { WP and Azoxystrobin } 23 \% \text { SC) reduced } \\
\text { the lesion expansion significantly. There was } 453.44 \% \text { increase in the lesion size over the } \\
\text { original lesion in control after } 96 \text { hours. Increase in lesion size was } 478.94 \% \text { in } \\
\text { Carbendazim 50\% WP. Significantly less increase in lesion size was recorded in } \\
\text { Ethaboxam } 40 \% \text { SC }(57.34 \%) \text { followed by Chlorothalonil } 33 \%+\text { Metalaxyl } 3.3 \% \text { SC } \\
(65.17 \%) \text {, Chlorothalonil } 75 \% \text { WP }(82.01 \%) \text {. and Azoxystrobin } 23 \% \text { SC (96.52\%). }\end{array}$} \\
\hline Keywords & \\
\hline $\begin{array}{l}\text { Late blight, Potato, } \\
\text { Fungicide, } \\
\text { Management }\end{array}$ & \\
\hline Article Info & \\
\hline $\begin{array}{l}\text { Accepted: } \\
\text { 04 December } 2017 \\
\text { Available Online: } \\
\text { 10 January } 2018\end{array}$ & \\
\hline & \\
\hline
\end{tabular}

\section{Introduction}

Potato (Solanum tuberosum L., Solanaceae) is 'The king of vegetables' has about 200 wild species in the world. Potato has become a staple food in many parts of the world. It is the world's fourth-largest food crop, following maize, wheat, and rice. There the potato developed as a temperate crop and was later distributed throughout the world largely as a consequence of the colonial expansion of
European countries. It was introduced to India by early 17 th century probably through British missionaries or Portuguese traders. It is an important cash crop throughout the world, used as staple food in many developing countries. At present, India ranks as the world's second largest potato producing nation after china. Potato is a highly nutritious, easily digestible wholesome food containing carbohydrates, proteins, minerals, vitamins and high quality dietary fiber. In 
every $100 \mathrm{~g}$ potato contains 87 per cent calories, 77 per cent water, protein $1.9 \mathrm{~g}$, carbs $20.1 \mathrm{~g}$, sugar $0.9 \mathrm{~g}$, fibers $1.8 \mathrm{~g}$ and $0.1 \mathrm{~g}$ fat, and good source of several vitamins and minerals, particularly potassium and vitamin $\mathrm{C}$ (Nutrition facts). It is most widely grown vegetable crop in the country with a share of 21.9 per cent area. The area under potato cultivation is 2060 thousand ha with total production of 44893 thousand MT with 21.8 MT/ha productivity. Uttar Pradesh is the leading potato growing state in the country with a production of 14315 thousand MT followed by West Bengal (10200.30 thousand MT and productivity 21.68 MT/ha) and Bihar (Horticulture Statistics Division 2015). Some important potato varieties under three maturity groups, i.e. early (70-80 days), medium (90100 days) and late (110-120 days) are commonly grown by the farmers in West Bengal condition are Kufri Jyoti, Kufri Chandramukhi, Kufri Lauvkar and Kufri Surya, Kufri Chipsona-1, Kufri Chipsona-2, Kufri Chipsona-3, Kufri Chipsona- 4, Kufri Himsona, Kufri Frysona.

Like other field crops potato is affected by a number of fungal, bacterial, viral and phytoplasma diseases (Mitchell, 2004). Among the diseases, Late blight caused by the fungus like oomycete pathogen Phytophthora infestans (Mont.) de Bary is a serious biotic stress of potato. A huge amount of yield loss occurs due to late blight. It is the most destructive of all potato disease and responsible for the Irish Famine in the middle of the 19th century. It affects both potato foliage in the field and tuber in the storage which can absolutely destroy a crop, producing a $100 \%$ crop loss (Tsedaley, 2014). It depends on degree of susceptibility of the cultivar, time of appearance of the disease, age of plant and other epidemiological factors. At present no true resistant source of the potato is available in the country, so chemical management is an indispensable component of
Integrated Disease Management (IDM) programme. New fungicides and biomolecules are introducing in the country every year against the fungal disease whose efficacy needs to be ascertained. But indiscriminate use of chemical pesticides are hampering ecological equilibrium, inviting resurgence problems and developing resistance strains. Indiscriminate use of systemic fungicides especially metalaxyl provides chance to develop resistant strain of the fungus has been reported from different parts of world (Sharma et al., 2015). Therefore, the present study was undertaken to find out suitable chemical to combat the diseases.

\section{Materials and Methods}

\section{Experiment site}

The field experiments were conducted at the Farmers' field situated at Binuria, Birbhum near PSB Agricultural Farm, Visva-Bharati, Sriniketan. The laboratory experiments were conducted at Department of Plant Protection, Palli Siksha Bhavana (Institute of Agriculture), Visva-Bharati. The experimental site is situated at an average altitude of 58.9 meter above msl and $23^{\circ} 39^{\prime} \mathrm{N}$ latitude and $87^{\circ} 42^{\prime} \mathrm{E}$ longitude. The experimental site comes under Sub-humid lateritic red and undulating agro-ecological zones of the tropics. The Experiment was done in 2015 2016.

\section{Sampling}

Some typical late blight lesions are identified and tagged accordingly in the field. The total leaf area and lesion size of 120 leaves were measured by using graph paper. The experiment was set up with RBD comprising of six treatments and four replications (Table 1). For each treatment there were five leaves. Suspension of different fungicides $(0.1 \%)$ were prepared and applied on the leaves with a 
hand sprayer. Expanded size of the spot after spraying was then measured at every 24 hours interval. Suitable untreated control was maintained for comparison. Individual size of the leaf and spot was measured and made average. From the primary data per cent area infected before spraying, per cent area infected after 4 days of spraying, per cent area increased after 4 days of spraying were calculated.

\section{Results and Discussion}

\section{Symptoms}

The disease appears as water-soaked irregular pale green lesions mostly near tip and margins of leaves which rapidly grow into large brown to purplish black necrotic spots. A white mildew, which consists of sporangia and spores of the pathogen, can be seen on lower surface of the infected leaves especially around the edges of the necrotic lesions. Light to dark brown lesions encircle the stems.

The affected stems and petioles become weak at such locations and may collapse. Entire crop gives blackened blighted appearance especially under disease favourable conditions and maybe destroyed within a week. Tubers in soil become infected by rain borne sporangia coming from the diseased foliage. Late blight infected tubers show irregular reddish brown to purplish areas which extend into internal tissues of the tubers. The infected tubers usually are hard, dry and firm but may get attacked by soft rot causing bacteria and rotin field and stores (International Potato Center, 1985; Arora, 2014).

\section{Pathogen}

Phytophthora infestans (Mont.) de Bary is an oomycete that causes the serious potato disease known as late blight or potato blight. The organism can also infect tomatoes and some other members of the Solanaceae. $P$. infestans is able to attack any part of the plant, including the leaves, stems and tubers. Sporangia of this pathogen may be dispersed over long distances by the wind, and the oospores can survive into the next growing season in the soil (Mayton et al., 2000). The thick-walled and robust oospores are formed as a result of sexual recombination. In contrast to sporangia, they can survive dry and cold conditions without a host. In the next growing season the germinating oospores can infect newly planted potatoes and cause early epidemics. However, the most important consequence of the occurrence of oospores is an increase in genetic variation within populations of $P$. infestans and the appearance of new, recombined strains (Andersson et al., 2009). In addition to oospores and air-borne sporangia, the infected seed tubers are another important source of late blight inoculums (Aylor, 2003).

\section{Effect of fungicides on lesion development in field condition}

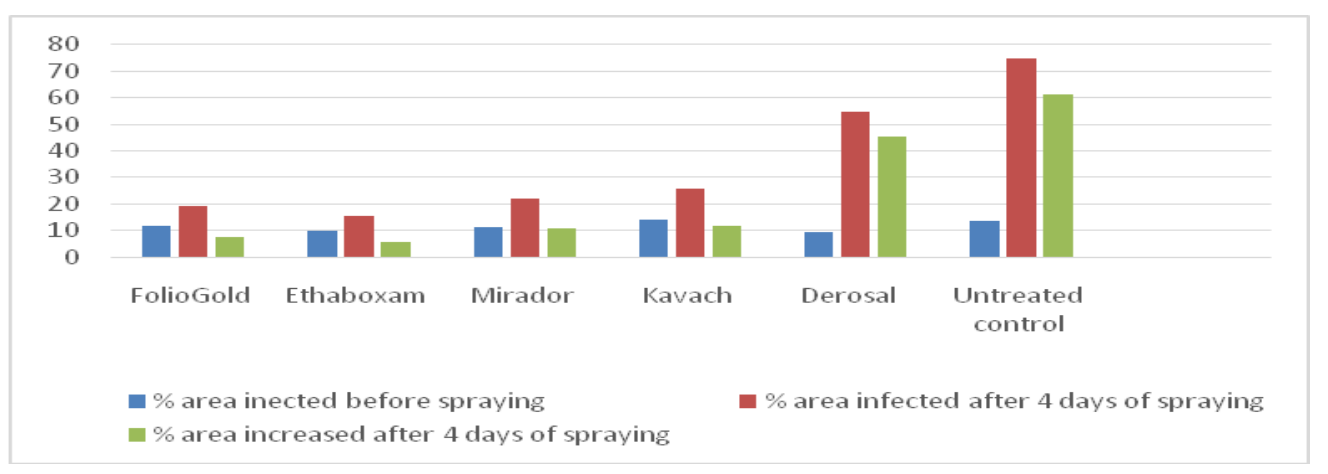



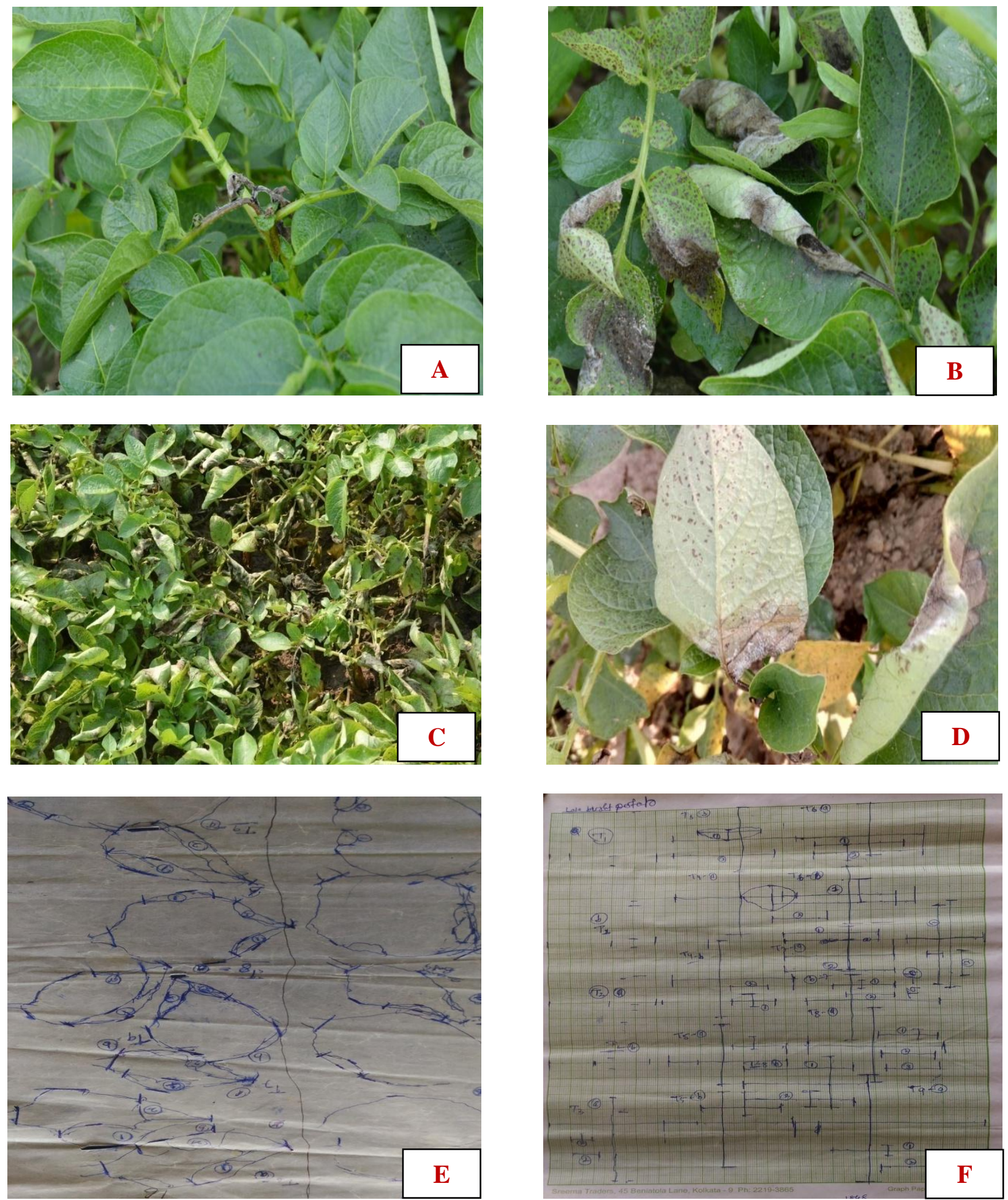

A: Symptoms on crown of the plant

B: Dark brown to black irregular water soaked lesions on the leaves with whitish fungal growth

C: Severely infected potato fields

D: Effect of fungicides for lesion development

E: Draw the lesion expansion size of infected leaf with tessing paper in field condition

F: lesion measured by using of graph paper 
Table.1 Fungicides used on lesion development in field condition

\begin{tabular}{|l|l|l|}
\hline Sl.No. & Fungicides & Active ingredient and formulation \\
\hline $\mathbf{1}$ & FolioGold (Syngenta India Ltd.) & Chlorothalonil 33\% + Metalaxyl 3.3\% SC \\
\hline $\mathbf{2}$ & Ethaboxam (Sumitomo Chemical India Ltd.) & Ethaboxam 40\% SC \\
\hline $\mathbf{3}$ & Mirador (SDS Ramcides CropSci. Pvt. Ltd.) & Azoxystrobin 23\% SC \\
\hline $\mathbf{5}$ & Kavach (Syngenta India Ltd.) & Chlorothalonil 75\% WP \\
\hline $\mathbf{5}$ & Derosal (Bayer Crop Science) & Carbendazim 50\% WP \\
\hline
\end{tabular}

Table.2 Effect of different fungicides on lesion development in field condition

\begin{tabular}{|c|c|c|c|c|c|c|c|}
\hline Treatment & $\begin{array}{l}\text { Origina } \\
\text { l avg. } \\
\text { leaf size } \\
\left(\mathrm{cm}^{2}\right) \\
\text { (A) }\end{array}$ & $\begin{array}{l}\text { Original } \\
\text { avg. size } \\
\text { of the } \\
\text { spot }\left(\mathrm{cm}^{2}\right) \\
\text { (B) }\end{array}$ & $\begin{array}{l}\% \text { area } \\
\text { infected } \\
\text { before } \\
\text { spraying } \\
{[\mathrm{C}=(\mathbf{B x} 100) /} \\
\text { A] }\end{array}$ & $\begin{array}{l}\text { Expanded size } \\
\text { of the spot } \\
\left(\mathrm{cm}^{2}\right) \text { after } 4 \\
\text { days of } \\
\text { spraying } \\
\text { (D) }\end{array}$ & $\begin{array}{l}\% \text { area } \\
\text { infected after } \\
4 \text { days of } \\
\text { spraying } \\
{[\mathrm{E}=(\mathrm{Dx} 100) /} \\
\mathrm{A}]\end{array}$ & $\begin{array}{l}\% \text { area } \\
\text { increased } \\
\text { after } 4 \\
\text { days of } \\
\text { spraying } \\
\text { (E-C) }\end{array}$ & $\begin{array}{l}\% \text { area } \\
\text { protected } \\
\text { after } 4 \text { days } \\
\text { of spraying } \\
\text { over control }\end{array}$ \\
\hline $\begin{array}{l}\text { FolioGold } \\
\text { (Chlorothalonil- 33\% + } \\
\text { Metalaxyl 3.3\% SC) }\end{array}$ & 28.59 & 3.36 & $\begin{array}{r}11.75 \\
(20.05)^{*}\end{array}$ & 5.55 & $19.41(26.14)$ & $7.66(16.07)$ & 87.53 \\
\hline Ethaboxam $40 \%$ SC & 29.53 & 2.86 & $9.69(18.14)$ & 4.50 & $15.24(22.98)$ & $5.55(13.63)$ & 90.97 \\
\hline $\begin{array}{l}\text { Mirador (Azoxystrobin } \\
23 \% \text { SC) }\end{array}$ & 28.25 & 3.17 & $11.22(19.57)$ & 6.23 & $22.05(28.01)$ & $\begin{array}{r}10.83 \\
(19.21)\end{array}$ & 82.38 \\
\hline $\begin{array}{l}\text { Kavach ( Chlorothalonil } \\
\text { 75\% WP) }\end{array}$ & 29.70 & 4.17 & $14.04(22.01)$ & 7.59 & $25.56(30.37)$ & $\begin{array}{r}11.52 \\
(19.84)\end{array}$ & 81.25 \\
\hline $\begin{array}{l}\text { Derosal (Carbendazim } \\
50 \% \text { WP) }\end{array}$ & 28.21 & 2.66 & $9.43(17.88)$ & 15.40 & $54.69(47.69)$ & $\begin{array}{r}45.26 \\
(42.28)\end{array}$ & 26.35 \\
\hline Untreated control & 25.68 & 3.48 & $13.55(21.60)$ & 19.26 & $75.00(60.00)$ & $\begin{array}{r}61.45 \\
(51.62)\end{array}$ & - \\
\hline $\operatorname{SEm}( \pm)$ & - & - & 0.87 & - & 1.56 & 1.30 & - \\
\hline $\mathrm{CD}(\mathrm{p}=0.05)$ & - & - & 2.45 & - & 4.25 & 3.81 & - \\
\hline
\end{tabular}

\section{Effect of different fungicides}

It was revealed from the experiment (Table 2) that infected area was recorded highest in the untreated control $(75.00 \%)$ followed by Bavistin (54.69\%) after 4 days of spraying whereas significantly lowest of that was recorded in Ethaboxam (15.24\%) followed by Folio Gold (19.41\%), Mirador $(22.05 \%)$ and Kavach (25.56\%). Same trends were also observed when per cent increment of spot area was calculated, and it was 5.55, 7.66, $10.83,11.52,45.26$ and $61.45 \%$ respectively for Ethaboxam, FolioGold, Mirador, Kavach, Bavistin and control.
Ethaboxam retarded lesion expansion more than did FolioGold, Mirador and Kavach. However, the difference was statistically insignificant $(\mathrm{p}=0.05)$ among the treatment FolioGold, Mirador and Kavach. Ethaboxam recorded best $(91.85 \%)$ followed by FolioGold (84.38\%), Mirador (73.30\%) and Kavach $(67.67 \%)$ when per cent area protected over untreated control was calculated. Negligible effect of that was recorded in case of Bavistin (26.35\%). It is clear from the Table 2 that Ethaboxam is the best fungicide followed by Folio Gold, Mirador and Kavachto combat against the disease. Bruck et al., (1981) reported the 
efficacy of mancozeb and chlorothalonil to retard lesion expansion of late blight of potato. He recorded that chlorothalonil reduced the rate of lesion expansion to about $64 \%$ over controls.

The experiment on the effect of fungicides on lesion development revealed that Bavistin had negligible effect to combat the disease whereas Ethaboxam retarded maximum lesion expansion than FolioGold, Mirador and Kavach. All the fungicides except Bavistin can be recommended to the farmers for managing their potato field against late blight disease.

\section{References}

Andersson, B., Widmark, A.K., Yuen, J.E., Nielsen, B., Ravnskov, S., Kessel, G.J.T., Evenhuis, A., Turkensteen, L.J., Hansen, J.G., Lehtinen, A., Hermansen, A., Brurberg, M.B. and Nordskog, B., 2009. The role of oospores in the epidemiology of potato late blight. Acta. Hort., 834, 61e 68.

Arora, R.K., Sanjeev, S., and Singh, B.P., 2014. Late blight disease of potato and its management. Central Potato Research Institute, Shimla 171 001, Himachal Pradesh, India.

Aylor, D.E., 2003. Spread of plant disease on a continental scale: role of aerial dispersal of pathogens. Ecology, 84, $1989 \mathrm{e} 1997$.

Bruck, R. I., Fry, W. E., Apple, A. E. and Mundt, C. C., 1981. Effect of protectant fungicides on the developmental stages of Phytophthora infestans in potato foliage. Phytopathology, 71:164-166.

Horticulture Statistics Division, 2015. Department of Agriculture, Cooperation and Farmers Welfare Ministry of Agriculture and Farmers Welfare Government of India.

International Potato Center, 1985. Field screening procedures to evaluate resistance to late blight. Technology Evaluation series-5. Lima, Peru. 17 pp.

Mayton, H., Smart, C.D., Moravec, B.C., Mizubuti, E.S.G., Muldoon, A.E. and Fry, W.E., 2000. Oospore survival and pathogenicity of single oospore recombinant progeny from 23 a cross involving US-17 and US-8 genotypes of Phytophthora infestans. Plant Disease, 84: 1190-1196.

Mitchell, P. L., 2004. Heteroptera as vectors of plant pathogens, Neotrop. Entomol. 33(5). Londrina.

Nutrition Facts and Health Effects, https://www.healthline.com/nutrition/fo ods/potatoes\#section 1

Sharma, P., Saikia, M. K. and Nath, B. C., 2015. A Review on Management of Late Blight of Potato through Host Resistance and Chemical Fungicides. The Biosciences, 8(17).

Tsedaley, B., 2014. Late blight of potato (Phytophthora infestans) biology, economic importance and its management approaches. Journal of Biology, Agriculture and Healthcare. 4(25): 215-225.

\section{How to cite this article:}

Saidul Islam, Rahamatulla Middya, Bholanath Mondal and Dinesh Chandra Khatua. 2018. Effect of Fungicides on Lesion Expansion of Late Blight of Potato. Int.J.Curr.Microbiol.App.Sci. 7(01): 20-25. doi: https://doi.org/10.20546/ijcmas.2018.701.003 